\title{
Modulation of sulfated proteoglycan synthesis and collagen gene expression by chondrocytes grown in the presence of bFGF alone or combined with IGF 1
}

\author{
V Nataf 1, L Tsagris 1, MF Dumontier 2, \\ J Bonaventure $1, M$ Corvol ${ }^{1 *}$ \\ 1 INSERM U30; 2 INSERM U12, Hôpital des Enfants Malades, \\ 149, rue de Sèvres, 75015 Paris, France
}

(15th meeting of the INRA Development group, Paris, 24-26 May 1989)

Summary - Prepubertal rabbit epiphyseal chondrocytes were grown in high density primary culture for $3 \mathrm{~d}$. They were then incubated for 3 additional $\mathbf{d}$ in serum-free culture medium to which bFGF $(1-50 \mathrm{ng} / \mathrm{ml})$ was added. During the last $24 \mathrm{~h}$ incubation period, either $\mathrm{IGF}_{1}(1-80 \mathrm{ng} / \mathrm{ml})$ or Insulin $(1-5 \mu \mathrm{g} / \mathrm{ml})$ was added to the culture medium. Chondrocyte DNA was significantly augmented with the increasing concentration of bFGF used, thus confirming its mitogenic effect on chondrocytes. On the other hand, bFGF was also shown to modulate the phenotypic expression of the chondrocytes. The ${ }^{35} \mathrm{~S}$-sulfate incorporation into newly synthesized proteglycans by the cultured cells decreased in a dose-dependent manner with bFGF concentration used. In addition, chondrocyte collagen gene expression was also shown to be modulated by bFGF. Total RNA extracted from the cultured cells was analyzed by dot blot and Northerm blot with cDNA probes encoding for $\alpha_{1} \|$ and $\alpha_{1} l$ procollagen chains.

A significant lower level of type II collagen mRNA, the marker of chondrocytic phenotype, was observed when cells were grown in the presence of bFGF while the level of type I mRNA remained unchanged. When IGF $F_{1}$ or a high concentration of insulin was added to the cells during the last $24 \mathrm{~h}$ of incubation with bFGF, sulfated proteoglycan synthesis, as well as collagen type II mRNA level, were significantly stimulated when compared with chondrocytes incubated with bFGF alone.

In conclusion, in the present experimental conditions, bFGF appears to be a growth promoting agent for chondrocytes in vitro with dedifferentiating action on chondrocyte phenotype. IGF 1 or insulin used at a high concentration can prevent the dedifferentiating effect of bFGF without inhibiting its stimulating effect on chondrocyte DNA synthesis.

proteoglycan / collagen / chondrocyte phenotype / bFGF, IGF / growth

Résumé - Modulation de la synthèse des protéoglycanes sulfates et de l'expression des gènes de collagène par des chondrocytes cultivés en présence de bFGF seul ou associé à IGF. Les chondrocytes épiphysaires de lapin prépubères sont mis en culture à haute densité cellulaire pendant $3 j$. Les cellules sont ensuite incubées pendant $3 j$ supplémentaires dans un milieu de culture sans sérum en présence de bFGF (1 à $50 \mathrm{ng} / \mathrm{ml}$ ). Pendant les dernières $24 \mathrm{~h}$ d'incubation,

* Correspondence and reprints 
on ajoute soit IGF 1 (1 à $50 \mathrm{ng} / \mathrm{ml}$ ), soit Insuline (1 ou $5 \mu \mathrm{g} / \mathrm{ml})$, soit rien. Le taux d'ADN cellulaire augmente en fonction de la concentration de bFGF utilisé, confirmant l'effet mitogène de ce facteur sur les chondrocytes. D'autre part, l'addition de bFGF au milieu de culture pendant 3 j modifie l'expression phénotypique des chondrocytes. En effet, la synthèse des protéoglycanes mesurée par l'incorporation de soutre 35 dans les cellules est diminuée de façon significative et cette diminution dépend de la concentration de bFGF présent dans le milieu. De plus, lexpression des gènes de collagène est modulée par l'addition de bFGF. Les ARN totaux des chondrocytes sont analysées par dot Blot et Northern Blot avec les sondes ADNc des procollagènes $\alpha_{1} \|$ et $\alpha_{1} l$. Quand les cellules sont incubées avec bFGF, on note une diminution significative des taux d'ARNm de collagène de type II, marqueur du phénotype chondrocytaire, alors que les taux d'ARNm de collagène de type I ne sont pas modifiés. L'addition d'IGF, ou de fortes concentrations d'insuline pendant les 24 demières $h$ d'incubation en présence de bFGF inhibe les effets observés avec bFGF seul : on observe en effet une augmentation de la synthèse des protéoglycanes sulfatés ainsi que des taux d'ARNm de collagène de type II. En conclusion, dans nos conditions expérimentales, le bFGF stimule la multiplication cellulaire des chondrocytes in vitro et a une action dédifférenciante sur le phénotype des chondrocytes. IGF, ou de fortes concentrations d'insuline peuvent prévenir l'effet dédifférenciant de bFGF sans inhiber son effet stimulant sur la synthèse d'ADN.

protéoglycanes / collagène / phénotype du chondrocyte / bFGF, IGF1 / facteurs de croissance

\section{INTRODUCTION}

It has been previously shown that bFGF is a potent mitotic agent for mesodermderived cells and particularly for chondrocytes in vitro (Corvol et al, 1972; Jones and Addison, 1975; Sachs et al, 1982). It has also been suggested that bFGF stabilizes the phenotypic expression of other cell types in culture, but its effect on chondrocyte differentiation remains unclear (Kato and Gospodarowicz, 1985). In addition, IGF $_{1}$ is originally considered to act as a systemic or autocrine regulator of cartilage growth and differentiation. Recent observations have suggested that bFGF and $I_{\text {GF }}$ could have a synergistic effect on growth and differentiation of muscle cells (Allen et al, 1985). This could also be the case for cartilage.

In the present study, the effects of bFGF-alone or combined with $\mathrm{IGF}_{1}$ on chondrocyte phenotype in vitro, were studied using a short term, high-density culture system of differentiated rabbit epiphyseal chondrocytes. Chondrocyte differentiation was followed at the protein level by the synthesis of sulfated proteoglycans and at the mRNA level by the expression of $\alpha 1 \mathrm{II}$. Chondrocyte dedifferentiation was studied by measurement of an increasing level of a1 I collagen mRNA.

\section{MATERIALS AND METHODS}

\section{Chrondrocyte culture}

The animals used were Fauve de Bourgogne prepubertal rabbits, $250-300 \mathrm{~g}$ body weight.

Primary cultures of chondrocytes were developed using rabbit epiphyseal cartilage from the hip, knee and shoulder according to Green (1971). After sequential enzymatic digestion of the cartilage tissue, the chondrocyte suspension was distributed either into 24 microwell tissue culture plates at a density of $8 \times 10^{4} \mathrm{cells} / \mathrm{w}$ ell for DNA measurement and ${ }^{35} \mathrm{~S}$-sulfate incorporation either into $75 \mathrm{~cm}^{2}$ culture flasks at a density of $8 \times 10^{5}$ cells/flask for RNA determination. The culture medium used was Ham $F_{12}$ supplemented with antibiotics (100 UI/ml penicillin, 100 $\mu \mathrm{g} / \mathrm{ml}$ streptomycin) and containing $10 \%$ fetal calf serum (FCS). The cells were incubated at 
$37^{\circ} \mathrm{C}$ in $5 \% \mathrm{CO}_{2}$ atmosphere. Three $\mathrm{d}$ later the chondrocytes formed multilayered non-confluent colonies. The culture medium was replaced by serum-free Dulbecco's medium to which basic fibroblast growth factor (bFGF) was added at a concentration ranging between $1-50 \mathrm{ng} / \mathrm{ml}$, and the cells were incubated for a further 3 days. In some experiments, $24 \mathrm{~h}$ prior to the end of incubation, the medium was replaced by fresh medium containing a similar concentration of bFGF and either $I_{G F}(1-80 \mathrm{~g} / \mathrm{ml})$, insulin (1 or $5 \mu \mathrm{g} /$ $\mathrm{ml}$ ) or nothing else. Cells incubated in serumfree Dulbecco's alone were used as controls.

\section{DNA measurement}

Chondrocytes grown in 24 well tissue culture plates were used for DNA measurement. After the $3 \mathrm{~d}$ incubation period in the presence or absence of bFGF, the medium was discarded, the cells were washed twice with Gey's balanced salt solution and trypsinized in EDTA - $0.25 \%$ trypsin for 15 min at $37^{\circ} \mathrm{C}$. DNA was measured by the fluorometric technique described by $\mathrm{Ka}$ puscinski and Skoczylas (1977). Results were expressed as the mean \pm SEM $\mu \mathrm{g}$ DNA per well of 4 similarly treated wells. In some experiments, an aliquot of the trypsin extract was also used for cell count in a hemocytometer and results were expressed as cell number per well. Results were compared to the amount of DNA or cell number observed in cultures completely grown in the presence of $10 \%$ FCS.

\section{S-sulfate-incorporation into chondrocyte proteoglycans}

Microwell tissue culture plates similar to those used for DNA measurement were prepared. After $2 \mathrm{~d}$ incubation in the presence or absence of bFGF, the cells were incubated in fresh serum and sulfate-free Dulbecco's medium containing : $1.5 \mu \mathrm{Ci} / \mathrm{ml}$ of $35 \mathrm{~S}$-sulfate to which $10 \mathrm{ng} / \mathrm{ml}$ bFGF was added alone or in combination with IGF $_{1}$ or insulin at the same concentrations as above. The incubation was performed at $37^{\circ} \mathrm{C}$ for $20 \mathrm{~h}$. Medium and cell layer were then treated separately with $3 \mathrm{~mol} / \mathrm{l}$ guanidinium hydrochloride in $0.05 \mathrm{~mol} / \mathrm{l}$ tris $\mathrm{HCl}$ buffer $\mathrm{pH} 7.4$.
Newly synthesized radio-labelled proteoglycans secreted by the cells were then purified onto a DEAE cellulose column with more than $75 \%$ recovery, and measured as previously described (Corvol et al, 1987). Aliquots of cell pellet and culture medium extracts were added separately to $5 \mathrm{ml}$ scintillation liquid and counted in a $\beta$ scintillation tricarb with an efficiency of $80 \%$. The counts were expressed as the means \pm SEM dpm/well of 4 similarly treated wells. Total amount of sulfated proteoglycans synthesized and secreted (cell + medium) by cultured chondrocytes in each well was then expressed as $\mathrm{dpm} / \mathrm{\mu g}$ DNA measured in similarly treated wells.

\section{Statistics}

Data reported as mean \pm SEM were compared using the Student's $t$ test. $P$ values $<0.05$ were considered to be statistically significant.

\section{RNA extraction and analysis}

Chondrocytes cultured in $75 \mathrm{~cm}^{2}$ flasks were incubated, as described above, in the presence or absence of bFGF for $3 \mathrm{~d}$ with or without IGF $_{1}$ or insulin added during the last $24 \mathrm{~h}$ incubation period. Groups of 4 similarly treated flasks were prepared. The guanidinium isothiocyanate $/ \mathrm{CsCl}$ method of Chirgwin et al (1979) was used to extract total cellular RNA from the chondrocytes. Fibroblasts total RNA was extracted from rabbit skin fibroblasts in culture.

Total RNA was denatured with a mixture containing formamide, formaldehyde and morpholine-propanesulfonic acid (Mops), according to the procedure described by Maniatis et al (1985). For dot blot analysis aliquots, (0.5, 1, 2 and $4 \mu \mathrm{g}$ ), were deposited directly on hybond $\mathrm{N}$ under vacuum. For Northern blot analysis, aliquots of 2 and $4 \mu \mathrm{g}$ of denatured RNA were run on $1 \%$ denaturing agarose gel and transferred to hybond $\mathrm{N}$.

Recombinant CDNA for bovine $\alpha_{1}$ ll procollagen (BC7) and human $\alpha_{1}$ l procollagen ( $\mathrm{Hf} 677$ ), kindly provided by Dr Ramirez (USA) (Chu ot al, 1982; Sangiorgi et al, 1985), were labelled by nick translation using [ $\left.\alpha^{32} \mathrm{P}\right]-d C T P(800 \mathrm{Ci} /$ $\mathrm{mmol}$ ). The mean specific activity observed was 
$2-4 \times 10^{8} \mathrm{cpm} / \mu \mathrm{g}$. The rat $\beta$ actin cDNA was used as an internal control.

The hybond membranes were prehybridized and hybridized at $42{ }^{\circ} \mathrm{C}$ for $4 \mathrm{~h}$ and $24 \mathrm{~h}$, respectively, in a solution containing $50 \%$ formamide, $5 X$ Denhardt's solution, $5 X$ SSPE, $0.5 \%$ SDS, $5 \%$ Dextran sulfate and $100 \mu \mathrm{g} / \mathrm{ml}$ salmon sperm DNA. The hybridization solution was supplemented with $4-8 \times 10^{6} \mathrm{cmp} / \mathrm{ml}$ of the appropriate cDNA probe.

After hybridization, the membranes were washed at $65^{\circ} \mathrm{C}$ several times with $2 \mathrm{X} \mathrm{SSC} /$ $0.1 \%$ SDS for $15 \mathrm{~min}$ and exposed to Cronex films for various time periods. Quantitative results were performed using scanning densitometry.

\section{RESULTS}

\section{Effect of bFGF on chondrocyte proliferation}

When primary cultured chondrocytes are incubated for $3 \mathrm{~d}$ in serum-free medium supplemented with bFGF at different concentrations, there is a dose-dependent increase in DNA content and cell number of the cultures, as shown in figure 1 . The ad-

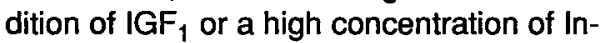
sulin during the last $24 \mathrm{~h}$ incubation period did not modify the chondrocyte DNA content (data not shown).

\section{Effect of $b F G F, I G F_{1}$ and Insulin on ${ }^{35}$ S-sulfate incorporation into chondrocytes}

The ${ }^{35} \mathrm{~S}$-sulfate incorporation into chondrocytes grown in serum-free medium supplemented with bFGF $(5,10$ or $50 \mathrm{ng} / \mathrm{ml})$ for $3 \mathrm{~d}$ decreases in a dose-dependent manner with the concentration of bFGF used. The total ${ }^{35} \mathrm{~S}$-sulfate incorporation (medium + cell) is observed, respectively, at $1.6 \pm 0.08 \times 10^{4}, 1.1 \pm 0.16 \times 10^{4}$ and $0.95 \pm 0.17 \times 10^{4} \mathrm{dpm}$ per $\mu \mathrm{g}$ DNA.

When $\mathrm{IGF}_{1}(1-40 \mathrm{ng} / \mathrm{ml})$ was added to these cultures during the last $24 \mathrm{~h}$ incubation period, there was an increase in ${ }^{35 S}$ sulfate incorporation (figure 2A). The maximum effect of IGF 1 is observed at $40 \mathrm{ng} / \mathrm{ml}$ in the presence of $10 \mathrm{ng} / \mathrm{ml} \mathrm{bFGF}$. Insulin added at a high concentration $(0.5,1$ or 5 $\mu \mathrm{g} / \mathrm{ml}$ ) also increases ${ }^{35} \mathrm{~S}$-sulfate incorporation with a maximum effect at $5 \mu \mathrm{g} / \mathrm{ml}$, but no significant variation occurs with the bFGF concentrations used (figure 2B).

\section{Effect of bFGF, IGF, and Insulin on mRNA level encoding the procollagen $\alpha_{1} /$ and $\alpha_{1} /$ chains}

The level of chondrocyte mRNA was studied after a $3 \mathrm{~d}$ incubation period in the presence of $10 \mathrm{ng} / \mathrm{ml} \mathrm{bFGF}$ and compared to chondrocytes grown in $10 \%$ FCS culture medium, and incubated with either $1 \%$ or $0 \%$ FCS during the last $20 \mathrm{~h}$ incubation period. Dot blot analysis of total RNA shows that the level of $\alpha_{1} \|$ mRNA is significantly lower in cultures developed in the pres-

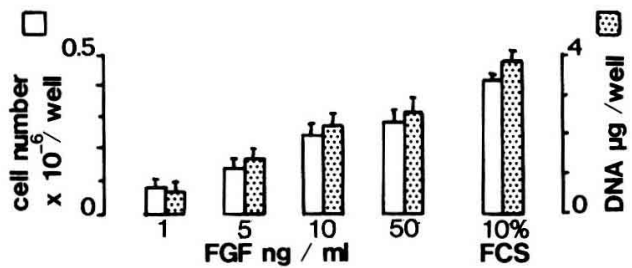

Fig 1. Effect of increasing concentration of bFGF on DNA and cell number. Chondrocytes were grown in primary culture for $3 \mathrm{~d}$ in the presence of FCS. They were then incubated for 3 additional $d$ in serum-free medium containing bFGF at different concentrations. DNA and cell number were measured and compared with results observed in cultures developed in the presence of $10 \%$ FCS. Each point represents the mean \pm SEM of 4 similarly treated culture wells. 
(A)
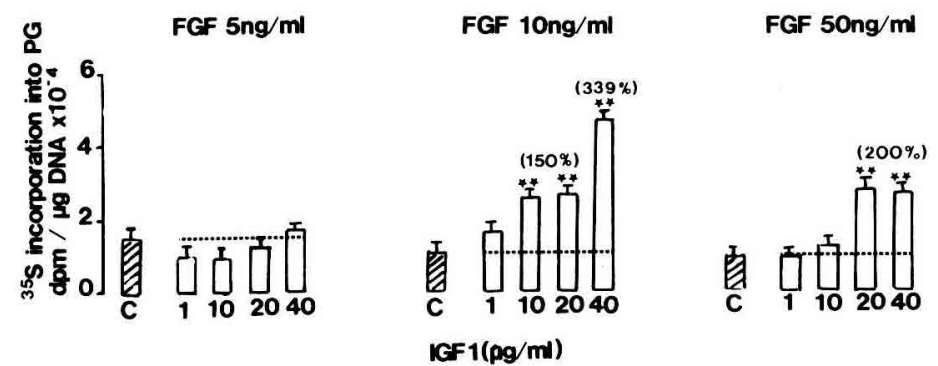

(B)
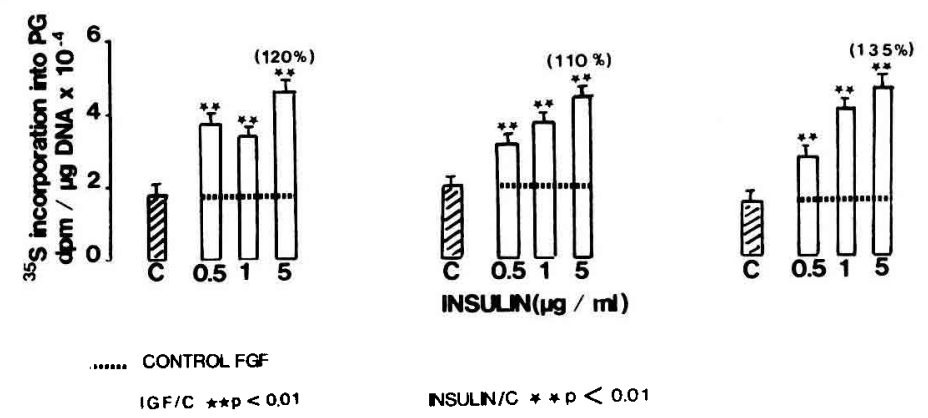

INSULN(pg / ms)

NSULN $/ C * p<0.01$

Fig 2. Effect of bFGF alone or combined with $\mathrm{IGF}_{1}$ or insulin on ${ }^{35} \mathrm{~S}$-Sulfate incorporation by cultured chondrocytes. Chondrocytes were grown in primary culture for $3 \mathrm{~d}$ with FCS. They were then incubated for 3 additional $d$ in serum-free medium to which bFGF was added at different concentrations. During the last $24 \mathrm{~h}$ incubation period, either IGF $_{1}$ or Insulin were added. ${ }^{35} \mathrm{~S}-S u l f a t e$ incorporation into newly synthesized proteoglycans was measured as in Methods. Results observed in chondrocytes treated with $\mathrm{bFGF}+\mathrm{IGF}_{1}$ or bFGF + Insulin were compared to chondrocytes incubated with bFGF alone. Each point is the mean \pm sem of 4 similarly treated wells. ${ }^{* *} P<0.01$.

ence of bFGF. Figure 3 represents 1 out of 3 experiments which show a significant 60 $\pm 10 \%$ lower level of $\alpha_{1} \|$ mRNA in the presence of bFGF than with $1 \%$ or $0 \%$ FCS. Control is performed using $\mathrm{BC} 7$ hybridization with total mRNA from cultured fibroblasts.

The level of $\alpha_{1}$ I mRNA is not modified, as measured by dot blot hybridization with a Hf 677 cDNA probe.

The combined effect of bFGF with IGF $_{1}$ $(2-20-80 \mathrm{ng} / \mathrm{ml})$ added to the cultures during the last $20 \mathrm{~h}$ incubation period was studied by Northern blot analysis of chondrocyte total RNA and is presented in figure 4.

The $\mathrm{CDNA} \mathrm{BC} 7$ probe demonstrates the presence of a single transcript of $5 \mathrm{~kb}$ in cultured chondrocytes with only very slight cross-hybridization with fibroblast collagen transcripts. $\mid \mathrm{GF}_{1}$ added at $2 \mathrm{ng} / \mathrm{ml}$, has no effect on $\alpha_{1}$ Il mRNA level, but at higher concentrations, it significantly increases Type II collagen mRNA in a dosedependent manner when compared to cells incubated with bFGF alone. 
Chondrocytes

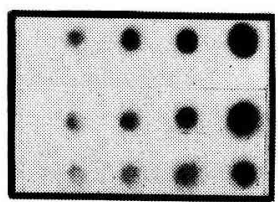

$1 \% F C S$

O\% FCS

FGF(10ng/ml)
Fibroblastes

CDNA

$\mathrm{Bc7}$

$1 \%$ FCS

0\% FCS

FGF (10ng/ml)
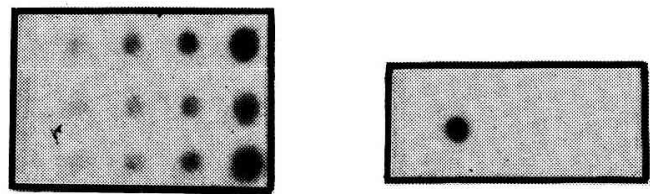

Hf677

Total RNA $(\mu \mathrm{g})$

0.5

\section{EFFECT OF FGF ON CHONDROCYTE PHENOTYPE}

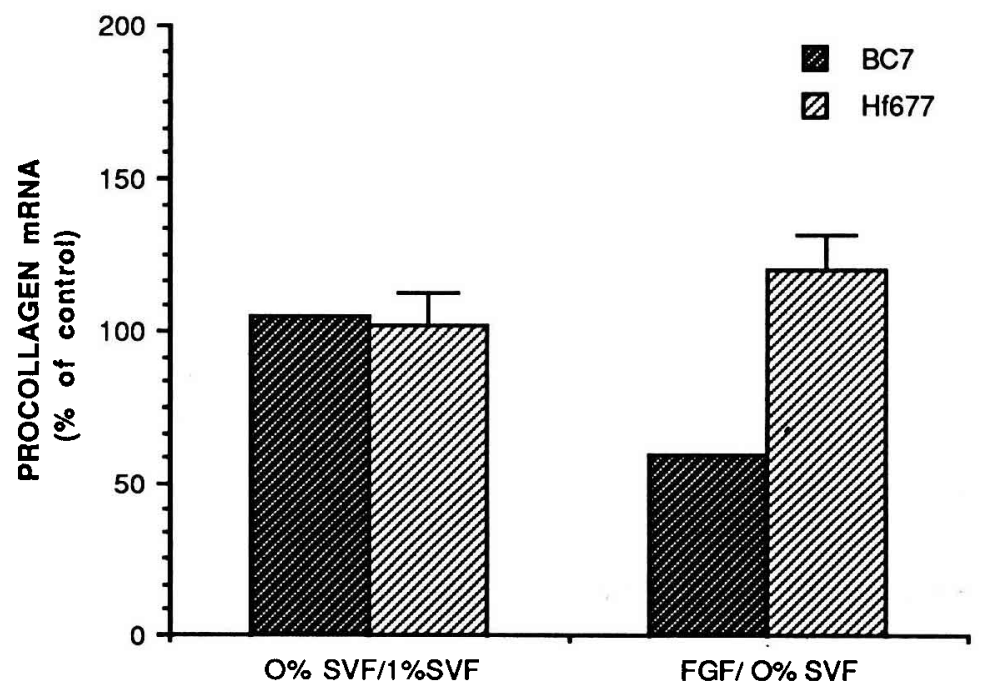

Fig 3. Dot blot analysis of total RNA extracted from chondrocytes cultured in the presence of bFGF $(10 \mathrm{ng} / \mathrm{ml})$ for $3 \mathrm{~d}$ and compared to cells incubated without bFGF, or with $1 \%$ FCS. Quantitative results were measured by densitometry and are represented on the diagram. 
bFGF, IGF 1 and chondrocyte phenotype

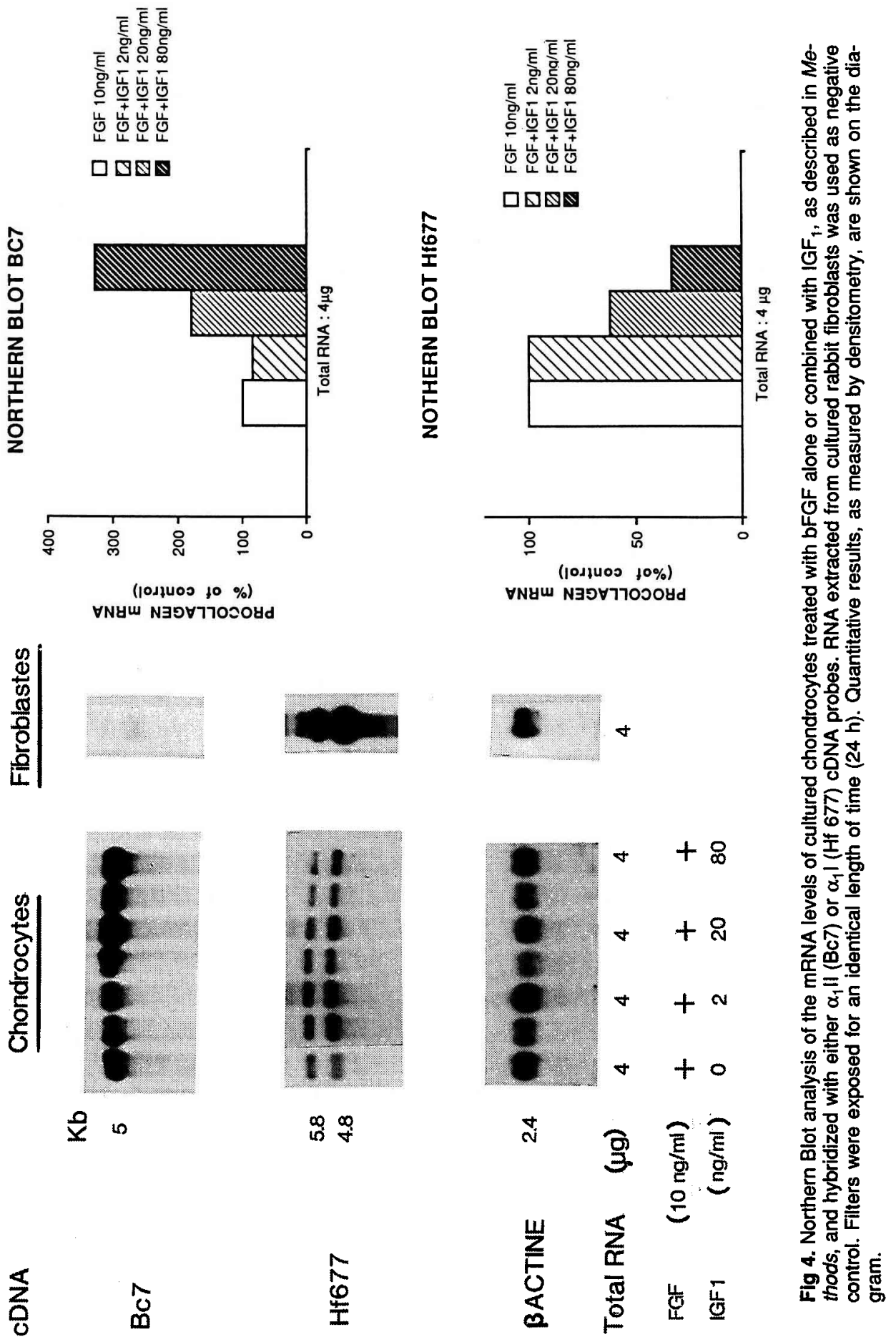


Hybridization with Hf 677 cDNA probe shows the 2 specific pro $_{1} \mid$ transcripts of 5.8 and $4.8 \mathrm{~kb}$ expressed in cultured fibroblasts. These transcripts are also detected in chondrocytes but at a lower level than in fibroblasts.

When IGF $_{1}$ is added to the cells at 2.20 or $80 \mathrm{ng} / \mathrm{ml}$, the $\alpha_{1} \mathrm{l}$ mRNA level represents $95 \%, 60 \%$, and $35 \%$, respectively, of that extracted from chondrocytes grown in the presence of $10 \mathrm{ng} / \mathrm{ml} \mathrm{bFGF}$ alone.

Insulin $(5 \mu \mathrm{g} / \mathrm{ml})$ has a similar effect as IGF $_{1}(40 \mathrm{ng} / \mathrm{ml})$ on $\alpha_{1} l$, as well as on $\alpha_{1}$ Il mRNA levels (fig 5).

\section{DISCUSSION}

The data presented in this paper elucidate some correlation between a dedifferentiating action of bFGF on chondrocytes and its growth promoting effect on these cells in vitro. In addition, IGF 1 appears to be able to reverse the dedifferentiating effect of bFGF on chondrocyte phenotype.

Differentiation and phenotypic expression of chondrocyte can be studied by expression of the main specific proteins synthesized by these cells, represented by proteoglycans of cartilage type and collagen type II. The recent availability to use specific cDNA probes for analysing mRNA procollagen chains allows us to study the co-ordinate regulation of different collagen genes in the same cells.

It is now well established that chondrocyte is phenotypically unstable in culture. Collagen type II mRNA is the major parameter of chondrocyte differentiation. When dedifferentiating, either spontaneously or in response to different agents, chondrocytes switch from type II to type I collagen synthesis (von der Mark et al, 1977) and first take up synthesis of $\alpha_{1}$ l mRNA, followed later by synthesis of $\alpha_{2}$ I
mRNA (Duchene et al, 1982). For this reason, cDNA encoding for $\alpha_{1}$ l procollagen mRNA was used in this study to follow the dedifferentiating process of cultured chondrocytes treated by the growth factors.

Cartilage has been suggested to be a target tissue for bFGF, which strongly stimulates DNA synthesis in chondrocytes in vitro (Pieter et al, 1982; Sachs et al, 1982). In addition, structural studies and recent cloning of bFGF gene (Esch et al, 1985) have shown its homology with many other growth factors, among which, the "cartilage growth factor" first purified from cartilage tissue by Klagsbrun et al (1986). It is now likely that bFGF may be produced by cartilage cells or by endothelial cells from the microvessels heading chondrocytes in the resting zone of growth plate cartilage, or even by bone cells surrounding the mineralized matrix of epiphyseal plate (Hauschka et al, 1986). bFGF could thus act either as an autocrine or paracrine growth factor in growth plate cartilage. However, the mechanism of action of this factor remains unclear. The widespread distribution of bFGF, as well as the wide range of cell types on which it acts, suggest that its growth promoting effect is not tissue specific (Gospodarowicz et al, 1987).

Indeed, in the present study, bFGF induces DNA synthesis and cell multiplication of cultured epiphyseal chondrocytes, but is also modulates chondrocyte metabolism in a dedifferentiating pass way. When incubated for $3 \mathrm{~d}$ in the presence of bFGF, the chondrocytes become elongated (data not shown), produce smaller amounts of sulfated proteoglycans and contain a lower level of type II collagen mRNA.

Such a dedifferentiating effect of bFGF on chondrocytes is in contradiction with the data presented by Kato and Gospodarowicz on cultured costal chondrocytes (Kato and Gospodarowicz, 1985). In fact, one can suggest that the positive effect of 
CDNA

Chondrocytes

Fibroblastes

$\mathrm{Kb}$

$\mathrm{Bc7}$

5
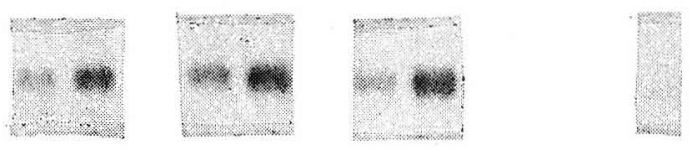

$\begin{array}{ll}H f 677 & 5.8 \\ & 4.8\end{array}$
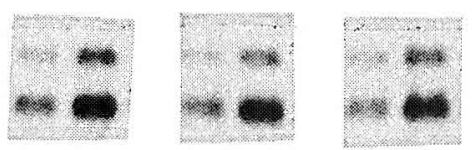

Total RNA $(\mu \mathrm{g})$

1.53

1.53

1.53

1

$\begin{array}{llll}\text { FGF }(10 \mathrm{ng} / \mathrm{ml}) & + & + & + \\ \text { IGF1 }(40 \mathrm{ng} / \mathrm{ml}) & - & + & - \\ \text { Insulin }(5 \mu \mathrm{g} / \mathrm{ml}) & - & - & +\end{array}$

\section{EFFECT OF IGF1 OR INSULIN ON CHONDROCYTE PHENOTYPE IN THE PRESENCE OF FGF}

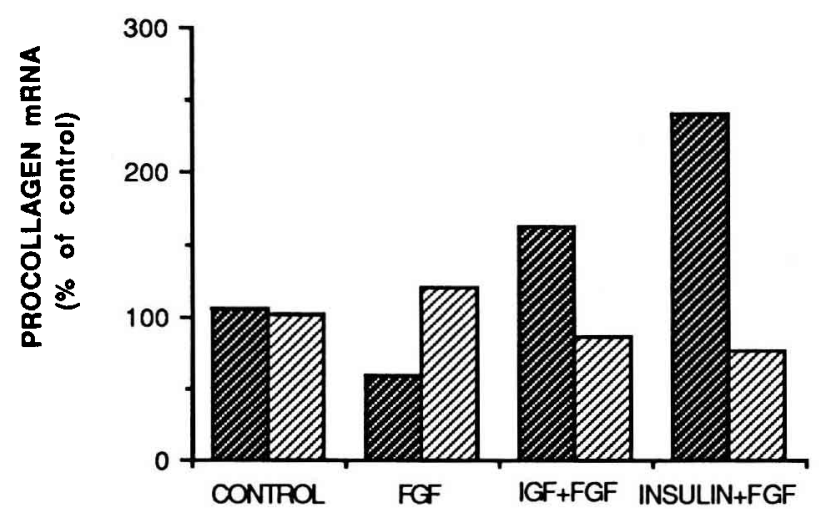

BC7

D Hf677

Fig 5. Northern Blot analysis of the mRNA levels of cultured chondrocytes treated with bFGF alone or combined with either $40 \mathrm{ng} / \mathrm{ml} \mathrm{IGF}_{1}$ or $5 \mu \mathrm{g} / \mathrm{ml}$ insulin. Hybridization with specific cDNA probes was performed as in fig 4. Quantitative results, as measured by densitometry, are shown on the diagram. 
FGF, observed at that time, was due to impurities contained in the bovine pituitary extract used. Other publications presented by the same group are in favour of this hypothesis. They first observed a stimulating effect of differentiation on myoblasts when using a crude FGF preparation (Esch et al, 1985), while an inhibition of differentiation was shown with a more purified bFGF preparation.

A dedifferentiating effect on cultured chondrocytes has also been described when using several other growth promoting agents, including the thymidine analog 5-BrDU, embryo extracts (Mayne et al, 1976), or serum (Gauss et al, 1981). In these studies, chondrocyte proliferation is enhanced and is followed by a progressive loss of type II collagen gene expression and a shift to the expression of a type I trimer $\left(\alpha_{1} l\right)_{3}$ and to collagen type $I\left(\alpha_{1} l\right)_{2}$ $\left(\alpha_{2} l\right)_{1}$. This dedifferentiating effect was suggested to be the consequence of the effect of growth factors on inducing the cells to enter the $S$ phase and to synthesize DNA, thus blocking the expression of cellular protein genes. It seems likely that in our experimental conditions, such a mechanism of action of bFGF could occur.

More recently, Spizz et al (1986) suggested that bFGF may also have a direct specific inhibitory effect on the phenotypic expression of muscle cells independently of its stimulating effect on cell proliferation. Our experimental conditions do not allow us to determine whether or not this direct effect occurs in chondrocytes. Further investigations, using non-dividing confluent chondrocyte colonies, will be useful answering this question.

In fact, bFGF has been proposed to act as a competence factor, as well as other factors such as PDGF, EGF (Jiminez de Asua et al, 1977), while another group of factors is responsible for the progression of normal diploid cells committed to divide by brief exposure to competence factor (Stiles et al, 1979). IGF, was proposed to be one major progression factor for cartilage growth (Adashi et al, 1984), with a specific stimulating effect on cartilage sulfation.

In the present study, the stimulating ef-

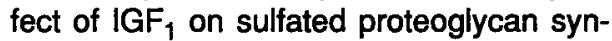
thesis is confirmed even in the presence of bFGF. IGF 1 thus appears to be able to either prevent or reverse the inhibitory effect of bFGF on proteoglycan synthesis, as was previously shown with insulin by Pieter et al (1982).

The stimulating effect of $\mathrm{IGF}_{1}$ on chondrocyte phenotype is even better characterized when looking at collagen gene expression. $I \mathrm{GF}_{1}$ is not only capable of enhancing type II collagen mRNA in bFGF treated cells, but also of reducing the expression of $\alpha 11$ procollagen chains. These data strongly suggest that $I_{\text {GF }}$ may be a major regulating agent of collagen gene expression in chondrocytes.

Similar effects on chondrocyte proteoglycan and collagen are observed with a high concentration of insulin, suggesting involvement of $I_{\text {GF }}$ receptors. There is also the possibility of interplay of both autocrine and exogenous action of IGF, on cartilage cells since chondrocytes have been shown to locally produce IGF $_{1}$ (Froger-Gaillard et al, 1989). It has been proposed by Zezulak and Green (1986) that IGF $_{1}$ could be one of the major factors stimulating the differentiation of mesenchym-derived cells such as chondrocytes or adipocytes. In this hypothesis, progenitor cells would be induced into the first step of differentiation by growth hormone and stimulated into the final differentiating process by $I_{\text {GF }}$, as shown for adipocytes by Doglio et al (1987). In the present study, the stimulating effect of $\mathrm{IGF}_{1}$ on chondrocyte differentiation, is observed even when these cells have previously 
been slightly dedifferentiated by bFGF. Whether of not there is a dissociation of $\mathrm{GH}$ and $\mathrm{IGF}_{1}$ action on chondrocyte phenotype, as was shown on adipocytes, remains to be seen.

\section{ACKNOWLEDGMENT}

This work was supported by INSERM. We thank MC Coridun who typed the manuscript.

\section{REFERENCES}

Adashi EY, Resnick CE, Svoboda ME, Van Wyk $J J$ (1984) A novel role for Somatomedin C in the cytodifferentiation of the ovarian granulosa cells. Endocrinology 115, 1227-1229

Allen RE, Dodson MV, Luiten LS, Boxhorn LK (1985) A serum-free medium that supports the growth of cultured skeletal muscle satellite cells. In Vitro Cell Dev Biol21, 636-640

Chirgwin JM, Przybyla AE, Mac Donald RJ, Rutter WJ (1979) Isolation of biologically active ribonucleic acid from sources enriched in ribonuclease. Biochemistry 18, 5294-5299

Chu ML, Myers JC, Bernard MP, Ding JF, Ramirez $F$ (1982) Cloning and characterization of five overlapping CDNAs specific for the human pro $\alpha_{1}$ l collagen chain. Nucleic Acids Res 10, 5925-5934

Corvol MT, Malemud CJ, Sokoloff L (1972) A pituitary growth promoting factor for articular chondrocytes in monolayer culture. Endocrinology 90, 262-271

Corvol MT, Carrascosa A, Tsagris L, Blanchard O, Rappaport R (1987) Evidence for a direct in vitro action of sex steroids on rabbit cartilage cells during skeletal growth: influence of age and sex. Endocrinology 120, 1422-1429

Doglio A, Dani C, Frederikson G, Grimaldi P, Ailhaud $G$ (1987) Acute regulation of insulinlike growth factor-I gene expression by growth hormone during adipose cell differentiation. $E M B O$

Duchene M, Sobel ME, Müller PK (1982) Levels of collagen mRNA in dedifferentiating chondrocytes. Exp Cell Res 142, 317-324
Esch $F$, Baird A, Ling $N$, Ueno $N$, Hill $F$, Denoroy L, Klepper R, Gospodarowicz D, Böhlen P, Guillemin R (1985) Primary structure of bovine pituitary basic fibroblast growth factor (bFGF) and comparison with the aminoterminal sequence of bovine brain acidic FGF. Proc Natl Acad Sci USA 82, 6507-6511

Froger-Gaillard $B$, Hossenlop $P$, Adolphe $M$, Binoux M (1989) Production of insulin-like growth factors and their binding proteins by rabbit articular, chondrocytes: relationship with cell multiplication. Endocrinology 124, 2365-2372

Gauss V, Müller PK (1981) Change in the expression of collagene genes in dividing and nondividing chondrocytes. Biochim Biophys Acta 652, 39-47

Gospodarowicz D, Ferrara N, Schweigerer L, Neufeld G (1987) Structural characterization and biological functions of fibroblast growth factor. Endo Rev 8, 95-114

Green WT (1971) Behaviour of articular chondrocytes in culture. Clin Orthop Relat Res 75, 248-260

Hauschka PV, Mavrakos AE, lafrati MD, Doleman SE, Klagsbrun M (1986) Growth factors in bone matrix: isolation of multiple types by affinity chromatography on heparinsepharose. J Biol Chem 261, 12665-12674

Jiminez de Asua L, O'Farell MK, Clinigan D, Rudland PS (1977) Temporal sequence of hormonal interactions during the prereplicative phase of quiescent 3 T3 fibroblasts. ProC Natl Acad Sci USA 74, 3845-3849

Jones KL, Addison J (1975) Pituitary fibroblast growth factor as a stimulator of growth in cultured rabbit articular chondrocytes. Endocrinology 97, 359-366

Kapuscinski J, Skoczylas B (1977) Simple and rapid fluorimetric method for DNA microassay. Anal Biochem 83, 252-257

Kato Y, Gospodarowicz D (1985) Sulfated proteoglycan synthesis by rabbit costal chondrocytes grown in the presence of fibroblast growth factor. J Cell Biol 100, 477-485

Klagsbrun M, Sasse J, Sullivan R, Smith JA (1986) Human tumor cells synthetize an endothelial cell growth factor that is structurally related to basic fibroblast growth factor. Proc Natl Acad Sci USA 83, 2448-2452

Maniatis T, Fritsch EF, Sambrook J (1982) Extraction, purification and analysis of mRNA 
from Eukaryotic cells. In: Molecular Cloning. A Laboratory Manual. Cold Spring Harbour, New York, 188-209

von der Mark K, Gauss V, von der Mark H, Muller $P$ (1977) Relationship between cell shape and type of collagen synthesized as chondrocytes lose their cartilage phenotype in culture. Nature 267, 531-532

Mayne R, Vail MS, Mayne PM, Miller EJ (1976) Changes in the type of collagen synthesized as clones of chick chondrocytes grow and eventually lose division capacity. Proc Natl Acad Sci USA 73, 1674-1678

Prins AP, Lipman JM, Sokoloff L (1982) Effect of purified growth factors on rabbit articular chondrocytes in monolayer culture. Arthritis Rheum 25, 1217-1227

Sachs BL, Goldberg VM, Moskowitz RW, Malemud CJ (1982) Response of articular chondrocytes to pituitary fibroblast growth factor (FGF). J Cell Physiol 112, 51-59
Sangiorgi FO, Benson Chanda V, de Wet WJ, Sobel ME, Ramirez F (1985) Analysis of cDNA and genomic clones coding for the pro $\alpha_{1}$ chain of calf type II collagen. Nucleic Acids Res 13, 2815-2826

Spizz G, Roman D, Strauss A, Olson EA (1986) Serum and fibroblast growth factor inhibits myogenic differentiation through a mechanism dependent on protein synthesis and independent of cell proliferation. $J$ Biol Chem 261, 9483-9488

Stiles CD, Capone GT, Scher CD, Antoniades HM, Van Wyk JJ, Pledger WJ (1979) Dual control of cell growth by somatomedins and "competence factors". Proc Natl Acad Sci USA 76, 1279-1283

Zezulak KM, Green H (1986) The generation of insulin-like growth factor 1 -sensitive cells by growth hormone action. Science 233, 551553 